\title{
FIRST RECORD OF FACCIOLA'S SORCERER, FACCIOLELLA OXYRHYNCHA (ACTINOPTERYGII, ANGUILLIFORMES, NETTASTOMATIDAE) FROM THE AEGEAN SEA
}

\author{
Semih LEBLEBİCI * , Okan ÖZAYDIN, and Elizabeth G.T. ERONAT \\ Faculty of Fisheries, Ege University, 35100, Bornova, Izmir, Turkey
}

Leblebici S., Özaydın O., Eronat E.G.T. 2010. First record of Facciola’s sorcerer, Facciolella oxyrhyncha (Actinopterygii, Anguilliformes, Nettastomatidae) from the Aegean Sea. Acta Ichthyol. Piscat. 40 (1): $83-85$.

\begin{abstract}
A specimen of Facciola's sorcerer, Facciolella oxyrhyncha (Bellotti, 1883), was caught for the first time in the central Aegean Sea, on January 2007 by a commercial bottom trawler at a depth of about $230 \mathrm{~m}$ on the muddy bottom of Southern Sigacik Bay, Aegean Sea, Turkey.
\end{abstract}

Keywords: Facciolella oxyrhyncha, Nettastomatidae, Aegean Sea, first record

The number of recorded Levantine and Aegean Sea fish fauna has been increasing in the recent past. These dramatic changes can be explained mainly by introduction of non-native species presumably as a result of shipping and ballast water discharge, mariculture of non-native species, global warming, etc. (Galil and Zenetos 2002). New deepwater fish records of additional Aegean Sea fauna are resulting from modern trawling vessels, from gradually more extensive fishing effort, and exploration of deeper areas and intensified deepwater studies
(Papaconstantinou 1988, Kaya and Bilecenoglu 2000). There are no previous records of Facciola's sorcerer, Facciolella oxyrhyncha (Bellotti, 1883) in the Aegean Sea. The presently reported study indicates that the species now exists in the Aegean Sea and it describes some of the most notable morphological features of this species.

A single specimen of Facciolella oxyrhyncha was caught by a commercial trawler from the depth of $230 \mathrm{~m}$ out of Sigacik Bay (lat 3759'440"N, long $026^{\circ} 49^{\prime} 816^{\prime \prime} \mathrm{E}$; Fig. 1) on 13 January 2007. The specimen was placed in

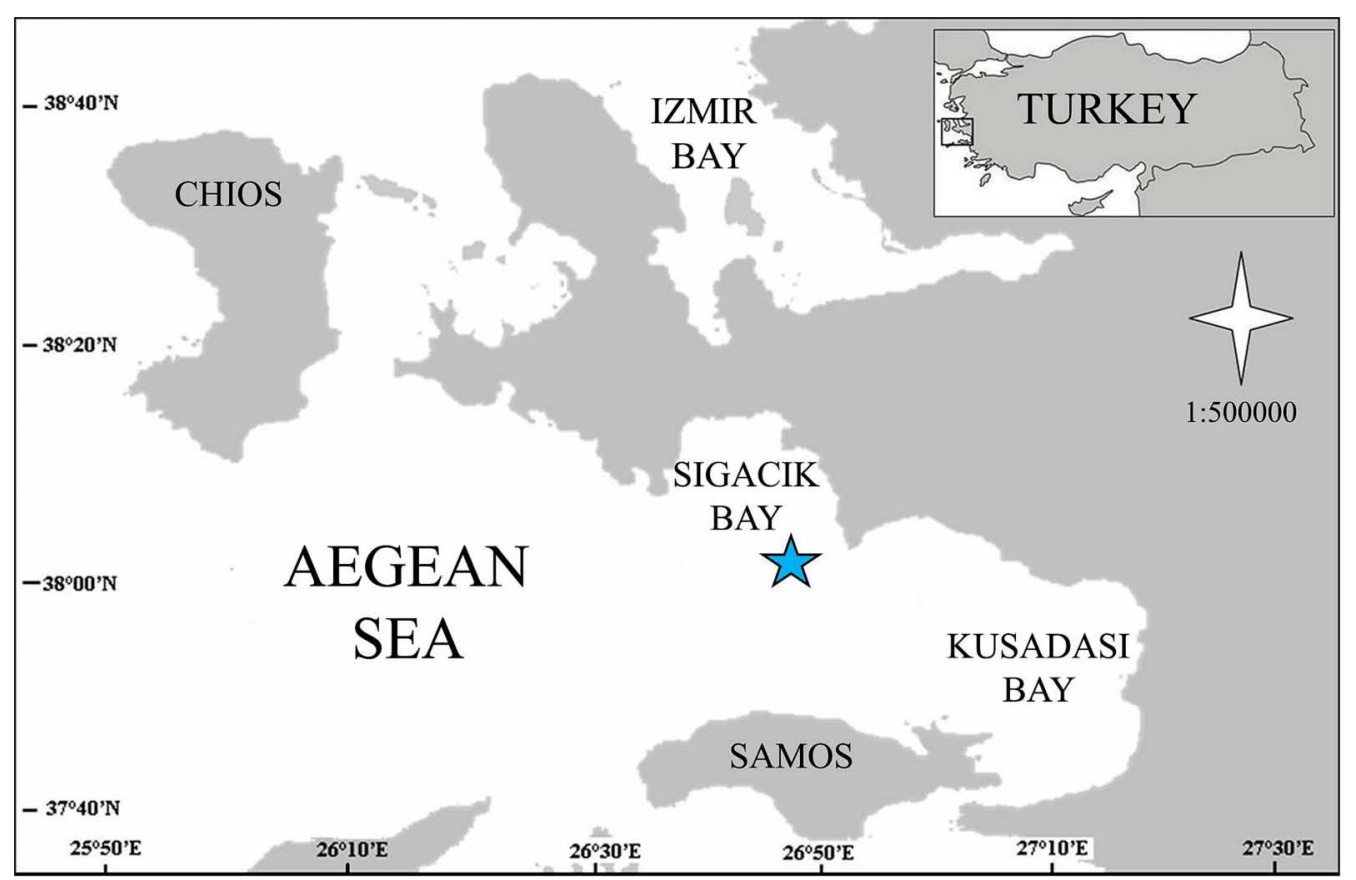

Fig. 1. The central Aegean Sea with the sampling locality of the described specimen of Facciola's sorcerer, Facciolella oxyrhyncha

\footnotetext{
* Correspondence: Dr. Semih Leblebici, Ege Üniversitesi, Su Ürünleri Fakültesi, Temel Bilimler Bölümü, 35100, İzmir, Türkiye, phone: +902323884000/1942, fax: +902323883685, e-mail: semih.leblebici@ege.edu.tr.
} 
a formalin solution (4\%), then put in an ethanol solution $(70 \%)$ and stored in the Museum of the Faculty of Fisheries, Ege University, Turkey (number: ESFM-PIS-2007-3). Morphometric characters were measured to the nearest $0.01 \mathrm{~mm}$ by a digital calliper and weighed to the nearest $0.0001 \mathrm{~g}$ using an electronic scale. Publications of Saldanha (1984), Smith (1990), and Golani et al. (2008) were used as a reference during fish species identification.

Morphometric features. Total Length $(\mathrm{TL}=333.31 \mathrm{~mm})$, body weight $(5.923 \mathrm{~g})$, Head Length ( $\mathrm{HL}=8.75 \% \mathrm{TL})$, preorbital length $(32.35 \% \mathrm{HL})$, eye diameter $(9.18 \% \mathrm{HL})$, inter-orbital distance $(5.69 \% \mathrm{HL})$, distance from snout to second nostril (17.02\% HL), second nostril diameter $(0.69 \% \mathrm{HL})$, gill opening diameter $(5.14 \% \mathrm{HL})$, body height $(22.72 \% \mathrm{HL})$, pre-dorsal length $(10.61 \% \mathrm{TL})$, dorsal fin length (89.39\% TL), pre-anal length $(31.57 \% \mathrm{TL})$, anal fin length $(68.43 \% \mathrm{TL})$, upper and lower jaw length (3.86\% and $3.32 \% \mathrm{TL})$, maximum mouth height and width $(2.86 \%$ and $2.73 \% \mathrm{TL})$.

Diagnostic Features. The body shape is rather elongated, anteriorly sub-cylindrical, compressed behind anus and the caudal region is tapered (Fig. 2). The head is separated from the trunk with a swelled line that surrounds the entire body. The head length is relatively short (about $9 \%$ of TL) and eyes are located at the origin of the mouth (Fig. 3). The inter-orbital distance is shorter than the eye's diameter. The outer rows of teeth are smaller than the inner rows, with irregular spacing. The inner rows of teeth are long, with pointed tips. The maximum mouth opening is approximately equal to the maximum mouth width. There is a projecting fleshy part on the front of tip of the snout. The first nostril occupies the tip of this fleshy part of the snout. The second nostril is located at the midpoint of the snout. The snout is beak-like and the upper jaw is slightly longer than the lower jaw. The gill opening is small and located ventrally at the back of the head. The dorsal and anal fins are confluent with the caudal fin, and the dorsal fin originates behind the gill opening from the front to the

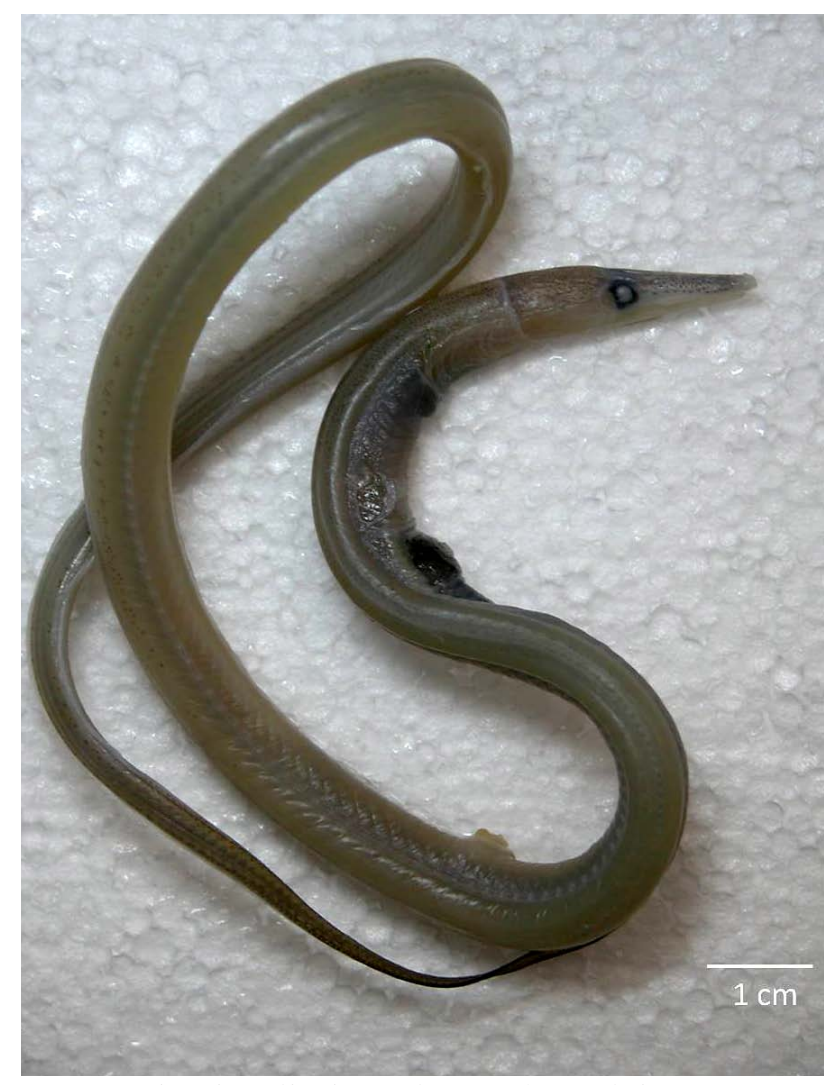

Fig. 2. The described specimen of Facciola's sorcerer, Facciolella oxyrhyncha; general view

anal opening. Pelvic and pectoral fins are absent. The body is a light grey colour. From the eyes to the snout there are three rows of black spots (approximately 22-24), and also a line of black spots beyond each side of the dorsal fin. The tip of the caudal fin is black. The anus is located before the midpoint. The specimen was female and ripe eggs were easily seen. Egg diameter range was between 0.35 and $0.99 \mathrm{~mm}$, mean and median values were $0.749 \pm 0.016$ (mean $\pm \mathrm{SE}$ ) and $0.78 \mathrm{~mm}$, respectively $(n=100)$.

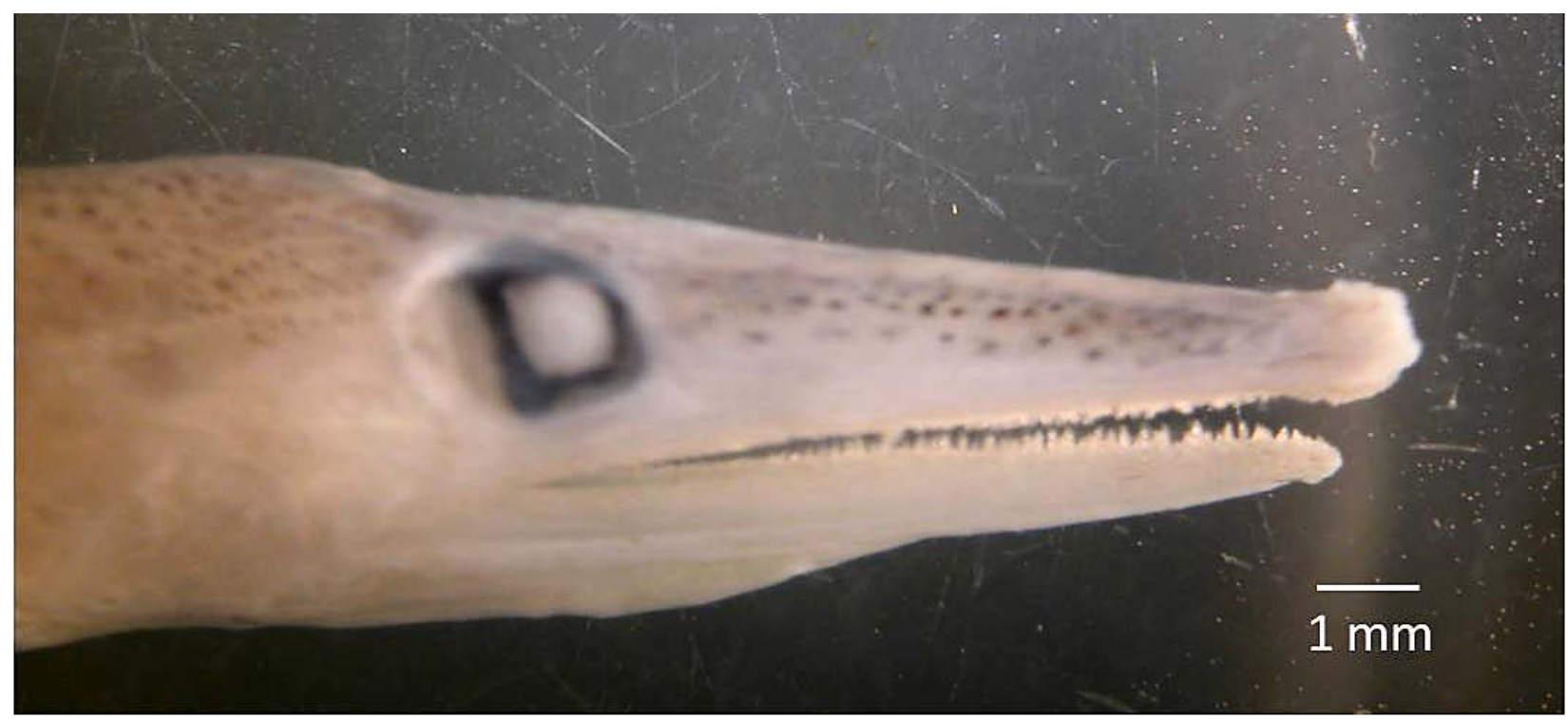

Fig. 3. The described specimen of Facciola's sorcerer, Facciolella oxyrhyncha; head; lateral view 
Facciolella oxyrhyncha is a rare benthic species inhabiting waters to depths of $731 \mathrm{~m}$ (Smith 1990). They are typically found in the Eastern Atlantic from Portugal to Angola (Saldanha 1984, Smith 1990). Genus Facciolella is represented with six valid species around the world oceans. From this genus, only $F$. oxyrhyncha is locally common in the Mediterranean Sea, characterised as native to this area (Froese and Pauly 2008) and typically is encountered from the Ligurian and Tyrrhenian seas to the western coast of Greece. Specimens have been recently recorded in the eastern part of Mediterranean (Saldanha 1984, Kaspiris 1984, Papaconstantinou 1988, Golani et al. 2008, Froese and Pauly 2008). Facciolella oxyrhyncha has been recently reported near the coasts of Antalya by Golani et al. (2008). The above-mentioned authors caught three $F$. oxyrhyncha individuals from Antalya Bay by a commercial trawler at depths of $300 \mathrm{~m}$. Specimens' total length (TL) measured between 183-410 $\mathrm{mm}$ and head length ranged between $8.7 \%-10.5 \% \mathrm{TL}$, preorbital length between $33.1 \%-36.7 \% \mathrm{HL}$, eye diameter 8.8\%-10.9\% HL, inter-orbital distance 3.1\%-3.3\% HL, but no information about sexes were provided. Saldanha (1984) mentioned gravid females throughout the year in his observations and not mentioned of locality. Our specimen appeared ready to reproduce in January in the Sigacik Bay, because of its ripe and somewhat hydrated eggs.

The number of recorded Levantine and Aegean Sea fish species are increasing day by day. This increase has several causes (such as climate change, Lessepsian migration etc.) also can be explained, especially for Turkish coasts, by an increase of detailed ichthyofaunistic studies. We believe that the number of known fish faunas of Aegean Sea and Levantine Sea will continue to increase with additional studies in the bathial and mesopelagic zones.

\section{ACKNOWLEDGEMENTS}

The authors would like to thank Ms. Lisa Randlette, Dr Tulin Coker and Dr Sencer Akalin for improving the manuscript and their valuable help and also to the crew and the captain of $F / V$ HAPULOGLU for their cooperation.

\section{REFERENCES}

Froese R., Pauly D. (eds.) 2008. FishBase. [version 01/2008] http://www.fishbase.org.

Galil B.S., Zenetos A. 2002. A sea change-exotics in the Eastern Mediterranean Sea. Pp. 325-336. In: Leppakoski E., Gollash S., Ollenin S., Dordrecht S. (eds.) Invasive aquatic species in Europe. Distribution, impacts and management. Kluwer Academic Publishers Boston, London.

Golani D., Gökoglu M., Güven O. 2008. Two new records of deep water fish species from the eastern Mediterranean. Marine Biodiversity Records (JMBA 2 - Biodiversity Records). DOI: 10.1017/S1755267206005410.

Kaspiris P. 1984. Anguilliformes from the western coasts of Greece. Biologia Gallo-Hellenica 11: 27-30.

Kaya M., Bilecenoglu M. 2000. New records of deep-sea fish in Turkish seas and the eastern Mediterranean. Journal of Ichthyology 40 (7): 543-547.

Papaconstantinou C. 1988. Fauna Graeciae. IV. Pisces. Checklist of marine fishes of Greece. Athens, Greece: National Centre for Marine Research, Hellenic Zoological Society, Athens.

Saldanha L. 1984. Nettastomidae. Pp. 562-566. In: Whitehead P.J.P., Bauchot M.-L., Hureau J.-C., Nielsen J., Tortonese E. (eds.) Fishes of the north-eastern Atlantic and the Mediterranean. UNESCO, Paris.

Smith D.G. 1990. Nettastomidae. Pp. 172-175. In: Quéro J.C., Hureau J.-C., Karrer C., Post A., Saldanha L. (eds.) Checklist of the fishes of the eastern tropical Atlantic (CLOFETA). UNESCO, Paris.
Received: 2 June 2009

Accepted: 7 December 2009

Published electronically: 25 June 2010 